\title{
Population, Deforestation and Biodiversity Erosion in the Context of Rural Agricultural Expansion in South Eastern Nigeria
}

\author{
Bisong, F. E. (PhD) \\ Department of Geography \& Regional Planning, University of Calabar, Nigeria. \\ Email: febisong@yahoo.com
}

\begin{abstract}
This study attempts to model the relationship between macro demographic factors at the aggregate village level data and the various indices of deforestation arising from rural agricultural expansion. In a multiple regression analysis of five (5) macro demographic (Causative) variables modelled against eleven (11) indices of deforestation (explanatory variables); the demographic factors critical to explaining variations in the various indices of deforestation were delineated. The population size of settlements, farm space density, and the size of households were identified to influence to various degrees, variations in deforestation indictors. The magnitudes of these effects were however, low, evident by low elasticities between population and deforestation variables.
\end{abstract}

\section{Introduction}

Population growth is generally reported in the literature as the major cause of environmental change and degradation (Philip, 1990; McNamara, 1992a; Ajaegbu, 1992a; Davis \& Bernstam, 1991). Soil deterioration, deforestation and loss in genetic and species diversity are factors now commonly associated with this phenomenon (Charkeseliani, 1990; Agarwal, 1992). Though the extent to which the population factor accounts for environmental damage has not yet between taken into consideration, few studies however delineate this specific contribution (Bilsborrow \& Delargy, 1991; Ajaegbu, 1992b; NEST, 1991; Aina \& Salau, 1992; Ologe, et al 1992). It is becoming evident in the literature that the population environment relationship cannot readily be cast in a unidirectional fashion (Davis \& Bernstam, 1991; Ajaegbu, 1992b), as attempted by McNamara (1992) and justified by Philip (1990).

A complex and multi-dimensional array of factor is now being identified as critical to environmental damage. These factors emanate from the nature of human interaction with the environment (Gourou, 1980; Carrey \& Schwartzberg, 1969; Salau, 1992; Salau, 1993). Thus other than relying on the pressures of human population as being solely responsible for environmental change; the size and growth rate of population, the level of technological capabilities, the level of human consumerism, mans social organization and the way man perceives his environment are presently being identified as the key 
factors that set the rules, method and rate at which the environment is exploited. (Bisong, 2001). Earlier studies on population and land use change sought to draw links between population densities, intensity of agriculture and food production (Boserup, 1965; Bisong, 2001; Mortimore, 1971; Morgan, 1955). The environmental consequence of the adaptation to population growth and pressure was however given little emphasis.

Later works however began to draw attention to some forms of environmental problems associated with man's interaction with the soils such as population pressure and the subsequent reduction in fallow as it affects soil desiccation, soil erosion and other forms of soil deterioration (Areola, 1990; Okai. 1992). A few studies in recent times have further extended the application of population and land use studies to the conservation needs have forest biodiversity (Myers, 1991; Zaba, 1991). The amount of forest cover available to each individual, a vital measure of forest pressure is estimated to have declined globally by $50 \%$ since 1960 to 0.6 hectares per person (Gardner-Outlaw \& Engelman, 1999). The observed decline in the ratio of forested land to human beings is attributed to population expansion (Gardner-Outlaw \& Engelman, 1999). An emerging viewpoint however holds that although population growth is a factor in natural resource depletion and environmental decline, the question of whether it is the Proximate or fundamental cause still remains to be proved (Global Biodiversity Support Program, 1999). Proponents of this view point holds that the population problem in the context of natural resource and biodiversity decline must be seen beyond the role of absolute numbers and density, and must incorporate other socio-economic variables as mediating between population and environment.

A distinction has therefore been made by some contributors between population and market-based explanations on deforestation (Angelson, 2000; Angelson, Shitindi \& Arrestad, 2000). In the context of the study region Lowe (1990) for instance, while reporting that the highest degree of species endemism in biological diversity in Africa occurs in the low land evergreen moist forest of the Cross River State, notes that the over-exploitation of the forest reserves through subsistence farming and cash cropping, hunting for bush meat, and logging activities pose a threat to the survival of these species and the maintenance of genetic diversity. Expanding further on the role of agriculture on deforestation and subsequent biodiversity decline, Philip (1990) maintains that deforestation in the Nigerian context has resulted largely from two processes: the increase in area of subsistence farming as a result of the need to feed a growing population; and the spread of cash crop by peasant farmers to obtain income (McNamara, 1992a).

Cash cropping is observed to have replaced forest cover in the high forest zone with the cultivation of tree crops such as cocoa, cola, oil palm and rubber for exports. The rising prices of foodstuffs have also resulted in the competition of arable crops for forestlands. Vast tract of land in Nigeria has as a result become devoid of forest as could be observed prior to 1970 where forest came to the road edges such as along Benin-Asaba, Obubra, Agoi and Arochukwu, Abakaliki roads. This forest has long disappeared. In Lowe's (1990) viewpoint, pressure on forest can be reduced if the productivity of arable land is enhanced. A number of other recent studies have called attention to the negative 
repercussions the loss in biodiversity will have on the prospects of feeding the growing human populations (Ehrlich, Enrlich \& Daily, 1993; Ehrlich, Enrlich \& Daily, 1993; Spore, 1993; Sattaur, 1991; Sasson, 1990). The common concern in all these studies is the disappearance or erosion of the once diverse range of plant and animal species as they are being replaced by the commercial uniform varieties or modern high yield varieties. The studies are also unanimous about the implication of these trends for social, economic and ecological security for agricultural and ecological systems. Although habitat destruction is identified as the major cause of biodiversity decline and extinction, and the factors of population growth and agricultural expansion are regarded as the major determinants of habitat destruction; the dearth of empirical data to justify these assertions and the poorly understood human and ecological factors within the rural agricultural processes, that serves to exacerbate further habitat destruction and subsequent biodiversity decline/erosion are significant gaps in the literature. This paper therefore seeks to quantify or delineate the effects of macro demographic factors on deforestation in the context of rural agricultural expansion; and to identify the deforestation indicators sensitive to demographic change.

\section{Materials and Method}

\section{Study Area}

Twelve settlements in the rainforest of Cross River State, South-Eastern Nigeria are the main focus of this study. They fall within the present Local Government Areas of Akamkpa, Ikom and Etung in the Cross River State. These regions are home to the Oban Division of the Cross River National Park and its associated support zones; the Cross River North and South Forest Reserves and the Ukpon, Umon, Oban East and West Reserves, including numerous tracts of Community Protected forest areas (Fig.1) The region occupies a land area of $7908.47 \mathrm{~km} 2$, or $42.8 \%$ of the total land area of the Cross-River State. It lies between latitudes 5"20 and 6"20N and longitudes 8"05 to 8" $45 \mathrm{E}$. About $70 \%$ of the high forest areas in the Cross River State, South Eastern Nigeria are confined within this zone. The Cross-River State in itself boasts of approximately $31 \%$ of the total remaining area of tropical high forest in Nigeria. The total forest Estate area of Cross River State including the Cross River National Park Covers approximately 7,290sq kms (35). The 1991 census estimates the entire population of the study area at 290,548 persons with Akamkpa and Ikom/Etung LGAs placed at 114,924 and 175,624 people respectively. While the overall state population density (crude) can be placed at 101 persons per $\mathrm{km}^{2}$, the Oban area (Akamkpa LGA) has a significantly lower population density at 22.8 Persons per $\mathrm{km}^{2}$. 


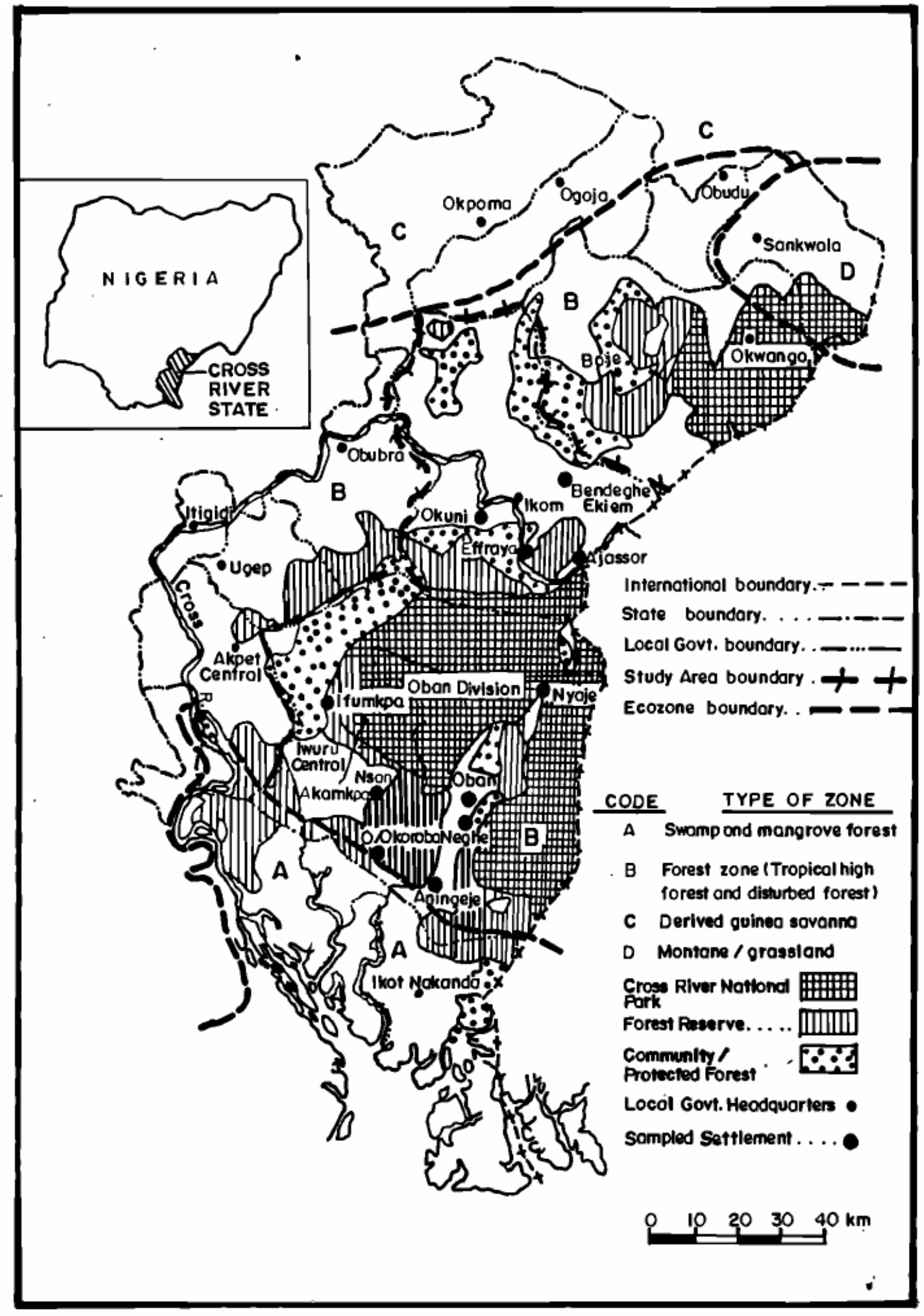

FIg. I : CROSS RIVER STATE SHOWING ECOLOGICAL ZONES, FOREST LAND-USE TYPES AND SAMPLED SETTLEMENTS 
The Ikom/Etung areas have a much higher density of 61 persons per $\mathrm{km}^{2}$. Agricultural land in the region is predominantly used for the cultivation of plantain and banana farms, perennial tree crop farms, homestead trees and gardens; and other staples such as cassava, cocoyam, maize, yam, melon, etc. $(36,37)$. Bush fallow cultivation is clearly dominant as it engages about $84 \%$ of the population.

\section{Method}

The study employed the use of questionnaire administered to 864 households in twelve (12) sampled settlements. The settlements were purposively selected based on their proximity to the different forest categories, but stratified to reflect the large, medium and low settlements with respect to their population sizes. The number and proportion of sampled households in each of the settlements are shown in Table 1.

The specific data collected were the demographic and socio- economic characteristics of the population, such is, the size of household dependency levels, population size of settlements and agricultural density. Data on land and forest use characteristics were also collected such as cropping and fallow patterns, average number and size of farm plot average size and frequency of forest clearings, and levels of floral and annual species extinction. With the use of aerial photographs, the size of deforested areas around each settlement was estimated. The multiple regression analysis was used to model the impact of demographic variables on deforestation indicators arising from agricultural causes.

\section{Results and Discussion}

An attempt is made quantify the effects of some selected macro demographic factors (for aggregate village level data) like average household size, dependency ratio, population size and farm space density on indices of deforestation such as crop area, crop/fallow area, total deforested area, flora and fauna species extinction etc. It is aimed at identifying the critical macro demographic variables responsible for deforestation and the extent and magnitude of their impact. In Table 2 is data used for the analysis. 
Table 1: Sampled Settlement And Attributes Of The Study Area

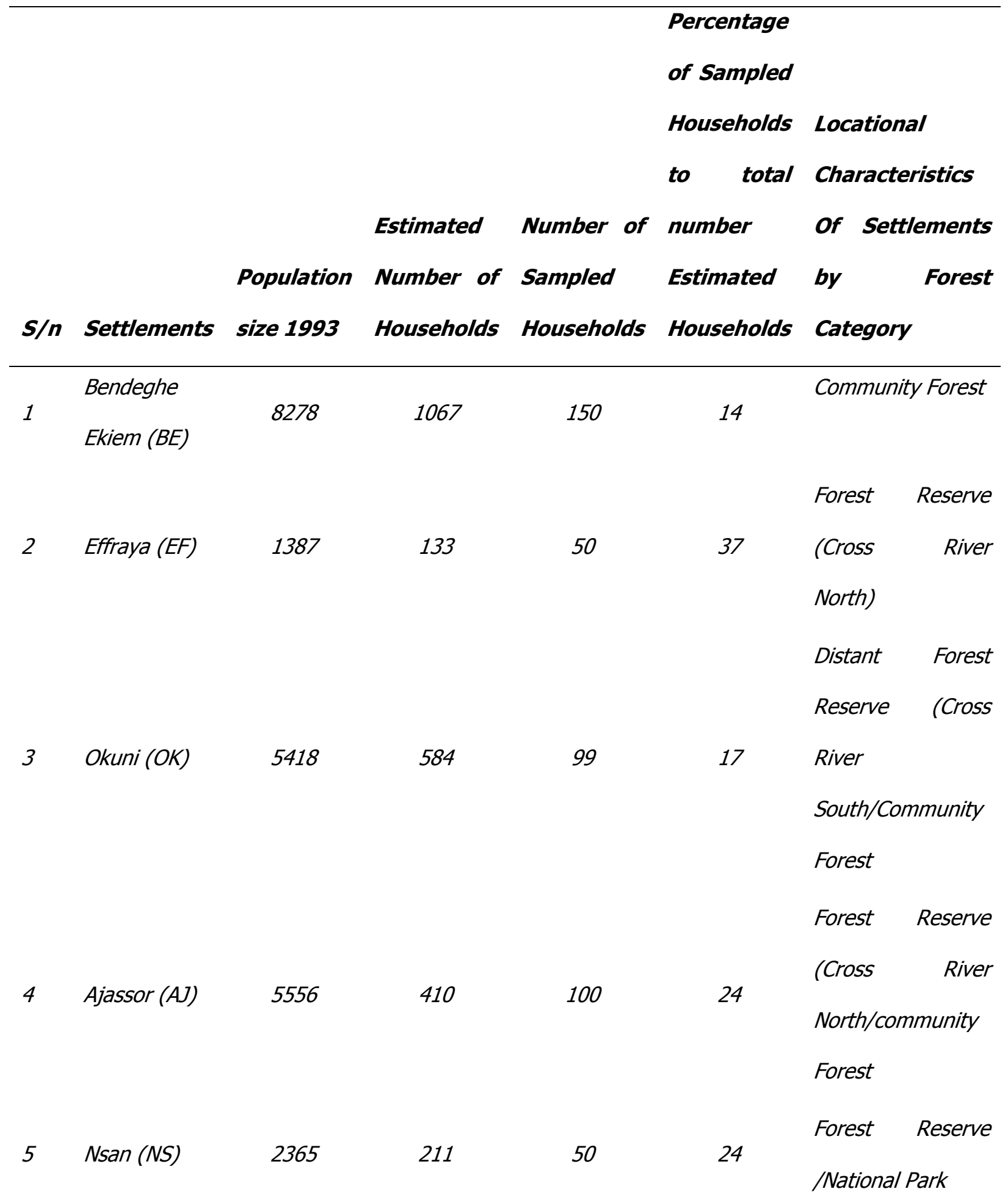


Oban

$6 \quad$ Okoroba

(OO)

$7 \quad$ Iwuru (IW)

1417

8 Ifumkpa (IF)

671

70

151

21

18

86

Enclave in Forest

Reserve (Oban

west)

Community Forest

Large Community

Forest/National

Park/Forest

Reserve

Community

Forest/ National

$9 \operatorname{Oban}(O B) \quad 3474 \quad 357$

78

22

Park/ Forest

Reserve

Community

$10 \quad$ Neghe (NJ) 590

70

38

54

park

Community

$11 \quad$ Nyaje (NJ)

1750

243

63

26

Forest/National

Park

Forest reserve/

Anningeje

12

$(A N)$

6710

902

121

11

Small community

forest

13 Total

37994

4038

864

21

The regression model is given by the equation:

\footnotetext{
$y=d_{0}+a_{1} x_{1}=a_{2} x_{2}+a_{3} x_{3}+a n_{4} x_{4}+a_{n} x_{n}+e$

Where: $\mathbf{y}=$ the dependent variable

$\mathbf{x}_{\mathbf{i}}=$ the $\mathrm{i}^{\text {th }}$ independent variable, $\mathrm{i}=1,2,3, \ldots, \mathrm{n}$
} 
$\mathbf{a}_{\mathbf{i}}=$ the regression parameter (coefficient) associated with the variable $\mathbf{i}$, $\mathbf{e}=$ the stochastic error term with the usual properties. 


\section{Table 2 Selected Demographic Variables and Deforestation in the Cross River Rainforest}

\begin{tabular}{|c|c|c|c|c|c|c|c|c|c|c|c|c|c|c|c|c|c|}
\hline Settlement & Row & C1 & $\mathrm{C2}$ & C3 & $\mathrm{C4}$ & C5 & C6 & C7 & C8 & C9 & $\mathrm{C10}$ & C11 & $\mathrm{C12}$ & C13 & C14 & C15 & C16 \\
\hline \multicolumn{18}{|l|}{ IKOM CHARGE } \\
\hline Bendeghe Ekiem (BE) & 1 & 7.76 & 31.85 & 51.85 & 8278 & 147.69 & 26.09 & 56.05 & 56.30 & 0.0068 & 16 & 16 & 9.40 & 27.72 & 7.016 & 3.15 & 56.30 \\
\hline Efraya $(\mathrm{EF})$ & 2 & 10.44 & 51.61 & 91.84 & 1387 & 31.37 & 19.17 & 44.21 & 54.18 & 0.0390 & 10 & 13 & 7.22 & 18.04 & 5.830 & 1.56 & 46.06 \\
\hline Okuni (OK) & 3 & 9.28 & 56.88 & 122.00 & 5418 & 88.92 & 33.45 & 60.93 & 61.15 & 0.0110 & 8 & 8 & 7.74 & 30.56 & 5.830 & 3.19 & 60.93 \\
\hline Ajassor (AJ) & 4 & 13.55 & 62.25 & 107.46 & 5556 & 189.04 & 10.73 & 29.39 & 32.79 & 0.0059 & 9 & 9 & 8.64 & 68.07 & 8.740 & 3.08 & 29.80 \\
\hline \multicolumn{18}{|l|}{ AKAMKPA CHARGE } \\
\hline Nsan (NS) & 5 & 11.22 & 68.75 & 120.41 & 2365 & 70.51 & 24.61 & 33.54 & 69.15 & 0.0290 & 5 & 10 & 3.70 & 6.86 & 5.250 & 0.44 & 33.57 \\
\hline Oban Okoroba (OO) & 6 & 9.00 & 67.77 & 122.00 & 378 & 204.32 & 0.38 & 1.85 & 2.18 & 0.0058 & 1 & 8 & 6.28 & 13.17 & 4.060 & 0.44 & 2.18 \\
\hline Iwuru (IW) & 7 & 9.10 & 90.78 & 154.00 & 1417 & 30.42 & 26.38 & 46.58 & 46.58 & 0.0330 & 6 & 13 & 7.30 & 22.57 & 6.030 & 3.67 & 46.30 \\
\hline Ifumkpa (IF) & 8 & 9.52 & 104.63 & 196.44 & 671 & 58.81 & 2.28 & 11.41 & 11.46 & 0.0170 & 5 & 8 & 3.08 & 8.10 & 3.640 & 4.15 & 11.46 \\
\hline \multicolumn{18}{|l|}{ OBAN CHARGE } \\
\hline Oban (OB) & 9 & 9.73 & 64.44 & 120.00 & 3474 & 65.33 & 47.37 & 53.18 & 13.86 & 0.0220 & 12 & 31 & 7.71 & 27.21 & 3.560 & 1.79 & 53.77 \\
\hline Neghe (NE) & 10 & 8.45 & 77.77 & 137.00 & 590 & 62.83 & 4.45 & 9.39 & 9.67 & 0.0160 & 24 & 24 & 4.89 & 10.13 & 3.710 & 1.68 & 9.67 \\
\hline Nyaje (NJ) & 11 & 7.21 & 64.18 & 105.57 & 1750 & 184.41 & 3.79 & 9.24 & 9.58 & 0.0055 & 8 & 19 & $\begin{array}{l}12.6 \\
3\end{array}$ & 24.63 & 4.700 & 3.79 & 9.47 \\
\hline Aningeje (AN) & 12 & 7.44 & 88.24 & 179.91 & 6710 & 197.75 & 32.75 & 37.33 & 55.95 & 0.0083 & 16 & 34 & 7.02 & 11.90 & 8.640 & 2.61 & 40.00 \\
\hline
\end{tabular}

SOURCE: Author's Field Data, 1994 
The variables reflected on the table are defined as follows:

$$
\begin{aligned}
& \mathrm{C} 1=\text { Average Household size } \\
& \mathrm{C} 2=\text { Dependency ration }(0-14 \mathrm{yrs})+65 \mathrm{yrs} \\
& \mathrm{C} 3=\text { Dependency ration }(0-19 \mathrm{yrs})+65 \mathrm{yrs} \\
& \mathrm{C} 4=\text { Population size } \\
& \mathrm{C} 5=\text { Farm space density } \\
& \mathrm{C} 6=\text { Cropping area }(\mathrm{sq} \mathrm{km}) \\
& \mathrm{C} 7=\text { Crop/fallow area }(\mathrm{sq} \mathrm{km}) \\
& \mathrm{C} 8=\text { Total deforested area }(\mathrm{sq} \mathrm{km}) \\
& \mathrm{C} 9=\text { Deforestation ratio } \\
& \mathrm{C} 10=\text { Animal species extinction } \\
& \mathrm{C} 11=\text { Flora species extinction } \\
& \mathrm{C} 12=\text { Average no. Of plots per person } \\
& \mathrm{C} 13=\text { Average plot size per person } \\
& \mathrm{C} 14=\text { Average size of recorded clearing } \\
& \mathrm{C} 15=\text { Average frequency of forest clearing } \\
& \mathrm{C} 16=\text { Deforested area net of government plantations. }
\end{aligned}
$$

The independent variables used in the regression analysis are average household size (C1), dependency ration 1-14 yrs. (C2), dependency ration 019yrs (03), population size (C4), farm space density (C5). The dependent variables are $\mathrm{C} 6$ to $\mathrm{Cl} 6$ as defined above. In the actual regression runs, $\mathrm{C} 2$ and C3 were found to be highly collinear. They returned a correlation coefficient of 0.967. This suggests that both cannot be used as independent variables in the same egression equation due to the factor of multi-collinearity. The actual regression analysis thus employs only four independent variables $(\mathrm{C} 1, \mathrm{C} 2, \mathrm{C} 4$ and $\mathrm{C} 5$ ) against eleven dependent variables (C6 to $\mathrm{C} 16)$. The regression results are presented in Table 3. In the regression between crop area (C6) on four independent variables $\mathrm{C} 1, \mathrm{C} 2, \mathrm{C} 3, \mathrm{C} 4$ and $\mathrm{C} 5$ three of the variables $\mathrm{C} 2$ (dependency ration), C4 (population size) and C5 (farm space density) were statistically significant with very low P-values. The P-values are reported in brackets below the parameter estimates they correspond. Population size $(\mathrm{C} 4)$ for instance has a P-value of 0.031 which implies that population size is statistically significant at 3.1 percent level.

The four variables $\mathrm{C} 1, \mathrm{C} 2, \mathrm{C} 4$ and $\mathrm{C} 5$ together accounted for about 59 percent of the total variation in C6 (crop area). In the case of the dependent variable $\mathrm{C} 7$ (crop/fallow area), the size of household (C1) and the dependency ratio (C2) were not statistically significant in explaining its total variation; whereas $\mathrm{C} 4$ (population size) and C5 (farm space density) were statistically significant in explaining the variation in C7. The four variables taken together accounted for 84 percent of total variation in $\mathrm{C} 7$. With respect to $\mathrm{C} 8$ (total deforested area) and C16 (deforested area net government plantations), only two variables C4 (population size) and C5 (farm space density) were found to be statistically significant in explaining changes in deforestation as reflected in variables $\mathrm{C} 8$ and $\mathrm{C} 16$. The four variable $(\mathrm{C} 1, \mathrm{C} 2, \mathrm{C} 4$, and $\mathrm{C} 5)$ jointly accounts for 68 percent of total variation in $\mathrm{C} 8$ and 73 percent of variation in $\mathrm{C} 16$. 
Table 3 Multiple regressional analysis of macro-demographic factors and deforestation

\begin{tabular}{|c|c|c|c|c|c|c|}
\hline \multicolumn{7}{|c|}{$\begin{array}{c}\text { The Regressional Equation: } \mathbf{C} \mathbf{j}=\mathbf{A} \mathbf{j}+\mathbf{A} 1 * \mathbf{C} \mathbf{1}+\mathbf{A} 2 * \mathbf{C} 2+\mathbf{A} \mathbf{3} * \mathbf{C} \mathbf{4}+\mathbf{A} 4 * \mathbf{C} \mathbf{5} \\
(\mathbf{j}=6,7, \ldots 16)\end{array}$} \\
\hline Row & C1 & $\mathrm{C2}$ & $\mathrm{C} 4$ & C5 & $\mathbf{R 2}$ & Crit \\
\hline C6 & $\begin{array}{l}-0.599 \\
(0.785)\end{array}$ & $\begin{array}{l}0.029 \\
(0.031)\end{array}$ & $\begin{array}{l}0.004 \\
(0.031)\end{array}$ & $\begin{array}{l}-0.131 \\
(0.063)\end{array}$ & 59 & $\mathrm{C} 2, \mathrm{C} 4, \mathrm{C} 5$ \\
\hline $\mathrm{C} 7$ & $\begin{array}{l}0.100 \\
(0.959)\end{array}$ & $\begin{array}{l}-0.176 \\
(0.369)\end{array}$ & $\begin{array}{l}0.006 \\
(0.01)\end{array}$ & $\begin{array}{l}-0.211 \\
(0.004)\end{array}$ & 84 & $\mathrm{C} 4, \mathrm{C} 5$ \\
\hline $\mathrm{C} 8$ & $\begin{array}{l}1.65 \\
(0.62)\end{array}$ & $\begin{array}{l}-0.133 \\
(0.74)\end{array}$ & $\begin{array}{l}0.007 \\
(0.02)\end{array}$ & $\begin{array}{l}-0.24 \\
(0.032)\end{array}$ & 68 & $\mathrm{C} 4, \mathrm{C} 5$ \\
\hline C9 & $\begin{array}{l}0.0009 \\
(0.48)\end{array}$ & $\begin{array}{l}-0.00004 \\
(0.76)\end{array}$ & $\begin{array}{l}-0.0000006 \\
(0.576)\end{array}$ & $\begin{array}{l}-0.00013 \\
(0.032)\end{array}$ & 76 & $\mathrm{C} 5$ \\
\hline $\mathrm{C} 10$ & $\begin{array}{l}-1.286 \\
(0.303)\end{array}$ & $\begin{array}{l}-0.008 \\
(0.946)\end{array}$ & $\begin{array}{l}0.0010 \\
(.318)\end{array}$ & $\begin{array}{l}-0.03 \\
(0.43)\end{array}$ & 28 & None \\
\hline $\mathrm{C} 11$ & $\begin{array}{l}-2.400 \\
(0.186)\end{array}$ & $\begin{array}{l}-0.115 \\
(0.513)\end{array}$ & $\begin{array}{l}0.0013 \\
(0.356)\end{array}$ & $\begin{array}{l}-0.0107 \\
(0.824)\end{array}$ & 33 & None \\
\hline $\mathrm{C} 12$ & $\begin{array}{l}-0.350 \\
(0.428)\end{array}$ & $\begin{array}{l}-0.064 \\
(0.174)\end{array}$ & $\begin{array}{l}-0.00001 \\
(0.972)\end{array}$ & $\begin{array}{l}-0.013 \\
(0.295)\end{array}$ & 47 & None \\
\hline $\mathrm{C} 13$ & $\begin{array}{l}5.75 \\
(0.034)\end{array}$ & $\begin{array}{l}-0.133 \\
(0.57\end{array}$ & $\begin{array}{l}0.0019 \\
(0.309)\end{array}$ & $\begin{array}{l}0.067 \\
(0.312)\end{array}$ & 43 & $\mathrm{C} 1$ \\
\hline $\mathrm{C} 14$ & $\begin{array}{l}0.316 \\
(0.196)\end{array}$ & $\begin{array}{l}0.020 \\
(0.406)\end{array}$ & $\begin{array}{l}0.0005 \\
(0.02)\end{array}$ & $\begin{array}{l}0.006 \\
(0.388)\end{array}$ & 51 & $\mathrm{C} 4$ \\
\hline $\mathrm{C} 15$ & $\begin{array}{l}-0.137 \\
(0.530)\end{array}$ & $\begin{array}{l}0.012 \\
(0.570\end{array}$ & $\begin{array}{l}-0.000005 \\
(0.970)\end{array}$ & $\begin{array}{l}0.0064 \\
(0.315)\end{array}$ & 0 & None \\
\hline $\mathrm{C} 16$ & $\begin{array}{l}0.08 \\
(0.907)\end{array}$ & $\begin{array}{l}0.19 \\
(0.35)\end{array}$ & $\begin{array}{l}0.006 \\
(0.003\end{array}$ & $\begin{array}{l}-0.213 \\
(0.005)\end{array}$ & 73 & $\mathrm{C} 4, \mathrm{C} 5$ \\
\hline
\end{tabular}

Notes: The values in brackets are the P-values

For variable C9 (deforestation ratio) which expresses the ratio of total deforestation area to the population size of settlements, only one of the four independent variable (C5) was statistically significant in explaining it at 3.2 percent level. All the four independent variables however jointly accounted for 76 percent of the total variation in $\mathrm{C} 9$ (deforestation ratio). None of the four independent variable $(\mathrm{C} 1, \mathrm{C} 2, \mathrm{C} 4, \mathrm{C} 5)$ were statistically significant in explaining the variations in variable C10 (Animal Species extinction), C11 (floral species extinction), C12 (average no. of farm plots per person) and C5 (average frequency score of forest clearing). Although the joint contribution of all variables accounted for $28 \%, 32 \%$ and $47 \%$ respectively in explaining variations in $\mathrm{C} 10, \mathrm{C} 11$ and 012.

Average size of household (C1) was interestingly found to be the only variable among the four independent variable as that was statistically significant in explaining the variations in $\mathrm{C} 13$ (the average plot size per person). The 
interesting aspect of the result is that household size had hitherto never showed up as being statistically relevant in explaining the variations in any of the dependent variables but only significant in relation to the size of farm plots. The result confirms earlier analysis of micro- demographic variables when household size was statistically significant in explaining the variations in forest resource use variable particularly that of size of farm plot (38). At the macro level analysis, it has shown up again as a critical factor (the only critical factor) in explaining variations in average size of farm plots per person (C13). It is critical at a 3.4 percent level i.e. about $97 \%$ confidence level and accounts for $43 \%$ of the total variation in average plot size per person. With respect to the average size of recorded clearing for survey area $(\mathrm{C} 14)$, only population size $(\mathrm{C} 4)$ among the four independent variables were critical in explaining its variation at 2 percent level. The combined impact of the four variables jointly accounts for 51 percent of the total variation in C14. Given the fact that multiple regression deals with the joint contribution of the independent variables on the dependent variable, it was average size of household (C1) was interestingly found to be the only variable among the four independent variables that was statistically significant in explaining the variations in $\mathrm{C} 13$, the average plot size per person).

The interesting aspect of the result is that household size had hitherto never showed up as being statistically relevant in explaining the variations in any of the dependent variables but only significant in relation to the size of farm plots. The result confirms earlier analysis of micro-demographic variables when household size was statistically significant in explaining the variations in forest resource use variable particularly that of size of farm plot (38). At the macro level analysis, it has shown up again as a critical factor (the only critical factor) in explaining variations in average size of farm plots per person (013). It is critical at a 3.4 percent level i.e. about $97 \%$ confidence level and accounts for $43 \%$ of the total variation in average plot size per person. With respect to the average size of recorded clearing for survey area (C14), only population size $(\mathrm{C} 4)$ among the four independent variables were critical in explaining its variation at 2 percent level. The combined impact of the four variables jointly accounts for 51 percent of the total variation in $\mathrm{C} 14$.

Given the fact that multiple regression deals with the joint contribution of the independent variables on the dependent variable, it was thought necessary to investigate further the contributions of each of the important independent variables on the various deforestation indices. The results are reported in Table 4. A profile of the result indicates that the dominant factor in deforestation is population size. It was statistically significant at whatever index of deforestation used. This was closely followed by farm space density. Both factors together accounted for $77.6 \%$ of the variation in deforestation indices such as the expansion of crop/fallow area, $48.6 \%$ variation in crop area, $58.5 \%$ variation in total deforested area, $67.1 \%$ variation in deforestation ratio and $48 \%$ of variation in the average size of clearing. They are all statistically significant in explaining the above stated variations at over 95\% confidence level or less than $5 \%$ level of significance.

Table 4 Regressional Analysis of Macro-Demographic Factors And Deforestation (Parameter Estimates Of The Regression Equation) 


\begin{tabular}{|c|c|c|c|c|c|c|}
\hline \multicolumn{7}{|c|}{$\begin{array}{c}\text { Regression Model: } \mathrm{Cj}=\mathrm{A} 1+\mathrm{A} 2 * \mathrm{C} 2+\mathrm{A} 3 * \mathrm{C} 3+\mathrm{A} 4 * \mathrm{C} 4 \\
(\mathrm{j}=6,7, \ldots \ldots .16)\end{array}$} \\
\hline & $\mathrm{C} 2$ & $\mathbf{C 3}$ & $\mathrm{C} 4$ & C5 & $\mathbf{R}^{2}$ & $\begin{array}{l}\text { Critica } \\
\text { Factors }\end{array}$ \\
\hline C6 & $\begin{array}{l}0.034 \\
(0.871)\end{array}$ & & $\begin{array}{l}0.0045 \\
(0.021)\end{array}$ & $\begin{array}{l}-0.129 \\
(0.05)\end{array}$ & 42.4 & $\mathrm{C} 4, \mathrm{C} 5$ \\
\hline C6 & & $\begin{array}{l}0.033 \\
(0.733)\end{array}$ & $\begin{array}{l}0.0045 \\
(0.015)\end{array}$ & $\begin{array}{l}0.129 \\
(0.047)\end{array}$ & 43.1 & $\mathrm{C} 4, \mathrm{C} 5$ \\
\hline C6 & $\begin{array}{l}-0.177 \\
(0.47)\end{array}$ & & & & 0.0 & \\
\hline C6 & & & $\begin{array}{l}0.003 \\
(0.068)\end{array}$ & & 22.4 & $\mathrm{C} 4$ \\
\hline C6 & & & & $\begin{array}{l}-0.058 \\
(0.105)\end{array}$ & 0.0 & \\
\hline C6 & & & $\begin{array}{l}0.0044 \\
(0.009)\end{array}$ & $\begin{array}{l}-0.128 \\
(0.36)\end{array}$ & 48.6 & \\
\hline C6 & $\begin{array}{l}0.0334 \\
(0.895)\end{array}$ & & $\begin{array}{l}0.0032 \\
(0.112)\end{array}$ & & 13.9 & \\
\hline $\mathrm{C} 7$ & & & $\begin{array}{l}0.007 \\
(0.00)\end{array}$ & $\begin{array}{l}-0.211 \\
(0.00)\end{array}$ & 77.6 & $\mathrm{C} 4, \mathrm{C} 5$ \\
\hline $\mathrm{C} 7$ & & & $\begin{array}{l}0.0049 \\
(0.026)\end{array}$ & & 34.6 & $\mathrm{C} 4$ \\
\hline $\mathrm{C} 7$ & & & & $\begin{array}{l}-0.093 \\
(0.38)\end{array}$ & 1.6 & \\
\hline C8 & & & $\begin{array}{l}0.0052 \\
(0.065)\end{array}$ & $\begin{array}{l}-0.122 \\
(0.013)\end{array}$ & 231.4 & $\mathrm{C} 4$ \\
\hline $\mathrm{C} 8$ & & & $\begin{array}{l}0.0079 \\
(0.004)\end{array}$ & $\begin{array}{l}-0.249 \\
(0.13)\end{array}$ & 58.5 & $\mathrm{C} 4, \mathrm{C} 5$ \\
\hline C9 & & & & $\begin{array}{l}-0.0015 \\
(0.0)\end{array}$ & 69.5 & $\mathrm{C} 5$ \\
\hline C9 & & & $\begin{array}{l}-0.0009 \\
(0.164)\end{array}$ & $\begin{array}{l}-0.0014 \\
(0.002)\end{array}$ & 10.3 & \\
\hline C9 & & & $\begin{array}{l}-0.0 \\
(0.618)\end{array}$ & $\begin{array}{l}-0.0014 \\
(0.002)\end{array}$ & 67.1 & $\mathrm{C} 4, \mathrm{C} 5$ \\
\hline C9 & & & -0.0 & $\begin{array}{l}-0.0014 \\
(0.002)\end{array}$ & 67.1 & C5 \\
\hline $\mathrm{C} 16$ & & & $\begin{array}{l}0.0049 \\
(0.028)\end{array}$ & & 33.7 & $\mathrm{C} 4$ \\
\hline $\mathrm{C} 16$ & & & $\begin{array}{l}-0.099 \\
(0.301)\end{array}$ & $\begin{array}{l}-0.099 \\
(0.301)\end{array}$ & 1.7 & \\
\hline $\mathrm{C} 13$ & $\begin{array}{l}5.211 \mathrm{C}_{1} \\
(0.062)\end{array}$ & & & & 23.8 & $\mathrm{C} 1$ \\
\hline $\mathrm{C} 14$ & & & $\begin{array}{l}0.005 \\
(0.006)\end{array}$ & & 50.9 & $\mathrm{C} 4$ \\
\hline $\mathrm{C} 14$ & & & $\begin{array}{l}0.00046 \\
(0.019)\end{array}$ & $\begin{array}{l}0.0042 \\
(0.525)\end{array}$ & 48.0 & $\mathrm{C} 4, \mathrm{C} 5$ \\
\hline $\mathrm{C} 16$ & & & $\begin{array}{l}0.000489 \\
(0.028)\end{array}$ & & 39.7 & $\mathrm{C} 4$ \\
\hline
\end{tabular}

Population size alone explains $23 \%$ of the total variation in deforested area, $33.7 \%$ of variation in deforested area net government plantations, $22 \%$ of variation in crop area, 35\% for crop/fallow area variations and $51 \%$ of variation in average area of recorded clearing for survey year. The above relationships are 
shown in Figures 2.to 2.4 representing the scatter plot with their respective lines up best fit.

No other demographic variable singularly recorded such feats among the macro-demographic factors in explaining the pattern of deforestation. The size of household is however critical in explaining the pattern of resource use where the natural resource use variable in question is the average size of farm plots per person. It explained $28 \%$ of the total variation in average per person plots size.

This relationship is visually represented in Figure 2.5. Farm space density expressed as the number of persons per unit of agricultural land is the next most critical variable to population size in explaining the deforestation phenomena. This variable however has no statistically significant effect on deforestation when acting alone. It yielded a rather insignificant level of explanation (1.4\%) with respect to the total variation in deforestation. Population size when acting alone exerts a positive impact on deforestation and accounts for $25 \%$ of total variation in deforestation area as earlier observed. Its impact on deforestation increases in concert with farm space density. We may therefore conclude that population size reinforces the effect of farm space density on deforestation and vice versa. They together account for $58.5 \%$ of total variation in deforestation area. The same pattern can be observed on the impact of population size and Farm space density on such indices of deforestation like crop area (C6) and crop/fallow area (C7). For instance the joint action of population size and farm space density account for $77.6 \%$ of total variation in the crop/fallow area (C7). Acting independently of each other, population size and farm space density accounted for $34.6 \%$ and $168 \%$ respectively of the total variation in the Crop/fallow area.

\section{Summary and Conclusion}

Population size and density are the most critical of the demographic variables at aggregate village level data that impacts positively on the various indices of deforestation. Farm space density however, had no significant statistical impact on most indices of deforestation except in conjunction with the population size of the settlements. The size of household was found to be critical only in explaining variation in the average size of farm plots, but yielded no such significance in explaining the variation in deforestation indicators. The above in a measure validates the research hypothesis that deforestation and forest resource use pattern; of communities in the Cross River State Rainforest, South-eastern Nigeria, is related to the micro and macro level demographic factory such as the size of households, the population size of settlements, firm space or agricultural density, and the dependency burden of the rural households. The magnitudes of their effects are however low due to the very poor elastic ties between population and deforestation variables.

\section{References}

Agarwal, A (1992). Social and Political Constraints to Biodiversity Conservation: a case from India in Sandlund, O.T., Hindar, \& Brown, A.H.D. (Eds). 
Conservation of Biodiversity for Sustainable Development Oslo, Scandinavian University Press.

Aina, T. A. and Salau, A. T. (1992). The Challenge of Sustainable Development in Nigeria Ibadan: Nigerian Environmental Study/Action Team (NEST).

Ajaegbu, H. I (1992b). Population and Environment Interrelationships in Africa: A Review Proceedings of the conference on Population and Environment in Africa. Gaborone, Botswana: UAPS, 1992). PP 1-15.

Ajaegbu, H. I. (1992a). Population trends and Agricultural and rural development In Africa. The search for suitable Population development Policies. Discussion paper presented at the 1992 Symposium of the African Development Bank on Population Policies for Sustainable Economic and Social Development in Africa. Dakar, 11th May.

Angelson, A. (2000). Agricultural expansion and deforestation: Modelling the impact of population, market forces and property rights. Journal of Development Economics 58: 185 - 218.

Angelson, A. Shitindi, E. F. K \& Arrestad, J. (2000). Why do Farmers expand their land into forests? Theories and Evidence from Tanzania, Environment and Development Economics 4: 313 - 331.

Areola, 0. (1990). The Good Earth Inaugural Lecture delivered at the University of Ibadan.

Bilsborrow, R. E \& Delargy, P. E. (1991). Land Use, Migration, and Natural Resource Deterioration; the Experience of Guatemala and Sudan in Davis, K. \& Bernstam, M. S. (eds) Resources. Environmental And Population: Present Knowledge. Future Options. Oxford University Press. 125-147

Bisong, F, E. (2001). Modelling Land-Use Patterns at the Forest Edge: An Analysis of the impact of Household Demographic Characteristics on forest Resource Use in South-Eastern Nigeria. Development Studies Round Table. Vol. 1 No 1. 1-18.

Bisong, F.E. (2001). Human Ecology and Natu1 a1 Resource Management Principles, Concepts and Applications. Port Harcourt: Double Diamond Publication, 1-109.

Boserup, E. (1965). Conditions of Agricultural Growth London: George Allen \& Unwin Ltd, 115- 136.

Carrey, G. W. \& Schwartzberg, J. (1969). Teaching Population Geography. New York: Teachers College Columbia University, 1-34.

Charkeseliani, P. (1990). Ecological Crisis and Developing Countries Social Science Quarterly Review vol. 21 No. 3

Davis, K. \& Bernstam, M. (1991) Resource, Environmental and PopulationPresent Knowledge, Future Options. Oxford: Oxford University Press. 259267.

Ehrlich, P. R, Enrlich, A. H \& Daily, G. C. (1993) "Food Security, Population, and Environment" in Population and development review vol 19. No. 1. 
FDD 1994. A Strategy for Sustainable Development Conservation and Management of the Forest Of Cross-River State. Cross River State: The Forestry Development Department.

Gardner-Outlaw, T. and Engelman, P. (1999). Forest Futures. Population. Consumption and Wood Resources. Washington D.C: Population Action International, 1-67.

Global Biodiversity Support Program (1999). African Biodiversity: Foundation for the future. A frame work for Integrating Biodiversity

Gourou, P. (1980). The Tropical World London: Longman.

Grove, A.T. (1961). Population Densities and Agricultural in Northern Nigeria in: Barbour, 1CM. and Prothero, P.M. (eds). Essays on African Population. London, Routledge \& Kegan Paul, 1, p115, 136.

Holland, M. D. 1989. Evolution and Agricultural Recommendations ODA/NRI Cross-River, Nigeria: National Park Oban Division Land.

Lowe, R. G. (1990). Nigeria statistics. Ibadan: University of Ibadan, Nigeria

McNamara, R.S (1992a). A Global Population Policy to Advance Human Development in the Twenty Fist Century, with particular Reference to SubSaharan Africa. Uganda: Global Coalitior for Africa. 1-51.

Morgan, W. B. (1955). Farming Practice, Settlement Pattern And Population Density in South-Eastern Nigeria in Prothero, R. M. 1972 (eds) People and Land in Africa South of the Sahara: Readings in Social Geography New York, Oxford University Press, 71-84

Mortimore, M. J. (1971). Population Densities and Systems Of Agricultural Land Use In Northern Nigeria. The Nigerian Geography Journal Vol. 14, No. 1 NGA.

Myers, N. (1991). The World's Forest and Human Population: The Environmental Interconnections in Davis .K. and Berstam, M. S. (eds) Resources. Environment and Populations: Present Knowledge, Future Options. Oxford: Oxford University Press, 237-251.

NEST, (1991). Nigeria's threatened Environment a National Profile. Ibadan, Nigerian Environmental Study/Action Yearn (NEST).

Okafor, J.C. (1989). Agro forestry Aspects. The WWF Oban Feasibility Study. 6th European development Fund.

Okai. M. (1992). The Consequences of Increasing Population Pressure For Land Carrying Capacity in Sub-Saharan Africa in Proceedings On The Conference on Population and Environment in African. Gaborone: Botswana, UAPs.

Ologe, K. O. et al (1992). Population and the Environment in Nigeria in Ama, T. A. and Salau, A. T. (eds) The Challenge of Sustainable Development In Nigeria. Ibadan: Nigeria Environmental study/Action Team (NEST).

Philip, P. (1990). Population And The Conservation of Nature In Population And Development Review Vol. 16 No. 2. 
Salau, A. T. (1993). Environmental Crises and Development in Nigeria. Inaugural Lecture Series No. 13 Port Harcourt: University of Port Harcourt, 138

Salau, A. T. 1992. Global Environmental Changes: A Research Agenda For Africa. Senegal Council for the Development of Social Research In Africa (CODESRIA).

Sasson, A. (1990). Feeding Tomorrow's World. UNESCO.

Sattaur, O. (1991). The Life Pool Under Threat. Panoscope: The Panas Institute.

Shand, H. (1993). Harvesting Nature's Diversity. World Food Day Italy, FAO.

Spore, (1993). Africa's Gene Pool: Sink or Swim. Netherlands, Technical Centre for Agricultural And Rural Cooperation (CTA).

Zaba, B. (1991). Population, Resource and Environment in Sub-Saharan Africa: Looking For the Linkages in Ajaegbu, H. I, (1992b) Population and environment Interrelationship in Africa: A Review Proceedings on the Conference on Population and Environment in Africa. Garborone Botswana: UAPS. 